Осадча О. О. [1; ORCID ID:0000-0003-1314-3281], д.е.н., професор

Павелко О. В. ${ }^{[1 ;}$ ORCID ID: 0000-0002-2483-2245], д.е.н., професор

${ }^{1}$ Національний університет водного господарства та природокористування, м. Рівне

\title{
МІКРОРІВЕНЬ ЕКОНОМІЧНОЇ БЕЗПЕКИ: ОБЛІКОВИЙ СУПРОВІД І ЗАБЕЗПЕЧЕННЯ ТРАНСПАРЕНТНОӦ ДІЯЛЬНОСТІ
}

У статті досліджено сутність економічної безпеки на мікрорівні та її функціональні складові. Визначено, що важливу роль у забезпеченні економічної безпеки суб'єкта господарювання відіграє система бухгалтерського обліку. Охарактеризовано основні функції облікової системи, які дозволяють підприємству досягати певного рівня економічної безпеки: інформаційну, правової регламентації, контрольну, прогностичну, регулюючу. Наведено основні бухгалтерські помилки, які підприємство повинно нейтралізувати з метою забезпечення економічної безпеки на мікрорівні. Обґрунтовано важливість інтегрованої звітності у забезпеченні транспарентної діяльності суб'єкта господарювання.

Ключові слова: мікрорівень; макрорівень; мезорівень; економічна безпека; облік; транспарентна діяльність; підприємство; звітність; організація бухгалтерського обліку.

Актуальність теми. В сучасних економічних реаліях за нестабільної політичної і соціально-економічної ситуації, що посилюється впливом світової пандемії, значна кількість господарюючих суб'єктів функціонує в умовах невизначеності. Ïх результати господарювання перебувають у безпосередній залежності від системи економічної безпеки, якісне налагодження якої становить надзвичайно актуальну проблему сьогодення, зважаючи на власну відповідальність господарюючих суб'єктів за успішність функціонування. Водночас в умовах посилення вимог до оприлюднення звітності, розширення міжнародної співпраці в частині розв'язання численних проблем екології користувачів обліково-звітної інформації передусім цікавлять нефінансові показники, що наводяться в інтегрованій звітності, які не рідко слугують основою ухвалення стратегічних і тактичних рішень. Саме транспарентність діяльності є викликом, що постає перед суб'єктами 
ринку, і сприяє залученню інвестиційних ресурсів. Це окреслює актуальність обраної тематики дослідження і потребує системного наукового вирішення.

Аналіз останніх досліджень і публікацій. Опрацювання теоретико-практичних засад побудови економічної безпеки на мікрорівні, забезпечення облікового супроводу, дослідження складу та структури інтегрованої звітності спостерігається в численних публікаціях вітчизняних науковців, зокрема таких, як О. Павелко [1]; Г. Козаченко, В. Пономарьов, О. Ляшенко [2]; М. Зацеркляний [3]; Д. Ковальов, Т. Сухорукова [5], Г. Козаченко, В. Пономарьов [6], Т. Васильців [7]) та ін.

Однак, незважаючи на значний внесок перелічених вище вчених у розвиток базових аспектів побудови економічної безпеки на мікрорівні, забезпечення облікового супроводу, дослідження складу та структури інтегрованої звітності, значна частка праць за окресленою тематикою має вузькоспеціалізований характер.

Постановка завдання. Мета дослідження полягає в ідентифікації сутності економічної безпеки на мікрорівні, окресленні доцільності формування належного облікового супроводу, висвітленні значення інтегрованої звітності для забезпечення транспарентності діяльності господарюючих суб'єктів.

Викладення основного матеріалу. Глобалізація світового господарства, активна інтеграція економіки України в міжнародні об'єднання, посилення конкурентної боротьби висувають перед суб'єктами ринку вимоги щодо посилення рівня власної економічної безпеки. Економічна безпека, безперечно, становить один із найбільш важливих функціональних напрямів національної безпеки країни, пріоритетну складову системи безпеки та характеризує стан захищеності життєво важливих інтересів суспільства [1, С.9]. Економічна безпека традиційно розглядається з трьох позицій: на макрорівні (економічна безпека країни загалом), мезорівні (економічна безпека окремого регіону), мікрорівні (економічна безпека конкретного господарюючого суб'єкта).

3 позиції мікрорівня економічна безпека - це:

- такий стан корпоративних ресурсів (ресурсів капіталу, персоналу та ін.) і підприємницьких можливостей, за якого гарантується найефективніше їх використання для стабільного функціонування та динамічного науково-технічного і соціального розвитку, запобігання внутрішнім і зовнішнім негативним впливам (загрозам) (Г. Козаченко, В. Пономарьов, О. Ляшенко [2]);

- стан ефективного використання ресурсів та існуючих 
ринкових можливостей підприємства, що дає змогу запобігати внутрішнім і зовнішнім загрозам, забезпечувати тривале виживання та стійкий розвиток на ринку відповідно до обраної ним місії (Г. Лянной [3, С. 17]);

- стан захищеності життєво важливих інтересів підприємства від внутрішніх і зовнішніх загроз (джерел небезпеки), який формується адміністрацією і колективом підприємства шляхом реалізації системи заходів правового, економічного, організаційного, інженерно-технічного і соціально-психологічного характеру (М. Зацеркляний [4, C. 15]);

- захищеність діяльності підприємства від негативних явищ зовнішнього середовища, а також здатність швидко усунути різноваріантні загрози або пристосуватися до існуючих умов, які не визначаються негативно на його діяльності (Д.Ковальов, Т. Сухорукова [5, С. 15]);

- гармонізація в часі та просторі економічних інтересів підприємства з інтересами, пов'язаних з ним, суб'єктів зовнішнього середовища, що діють за межами підприємства (Г. Козаченко, В. Пономарьов [6, С. 4]);

- стан функціонування, при якому підприємство та його продукція $€$ конкурентоспроможними на ринку, а також одночасно гарантується: найбільш ефективне використання ресурсів, інтелектуального та кадрового потенціалу; стабільність функціонування та прогресивність розвитку; можливість протистояти негативним впливам зовнішнього та внутрішнього середовища його функціонування (Т. Васильців [7, С. 18]).

Зважаючи на викладене вище, вважаємо за доцільне під економічною безпекою підприємства розуміти стан захищеності підприємницького потенціалу від внутрішніх і зовнішніх загроз, які спрямовані на дестабілізацію збалансованого розвитку, або ж такий стан функціонування, за якого максимально ефективно використовуються наявні ресурси 3 метою стабільного функціонування та динамічного розвитку, а також при цьому забезпечується незалежність, стійкість, можливість прогресу та уникнення внутрішніх і зовнішніх негативних дестабілізуючих факторів.

Функціональними складовими економічної безпеки традиційно вирізняються:

- фінансова (Барановський О., Мунтіян В., Мосіюк М., Зубок М., Рубцов В., Васильєв О., КозаченкоГ., Глушков В., Зайченко В., 
Ушкаренко Ю.);

- інтелектуальна і кадрова (Барановський 0., Мунтіян В., Мосіюк М., Зайченко В., Ушкаренко Ю.);

- техніко-технологічна (Барановський О., Мунтіян В., Мосіюк М., Козаченко Г., Глушков В., Зайченко В.);

- технологічна (Зубок М., Рубцов В.);

- виробничо-технологічна (Ушкаренко Ю.);

- політико-правова (Барановський О., Мунтіян В., Мосіюк М., Васильєв О., Козаченко Г., Зайченко В., Ушкаренко Ю.);

- інформаційна (Барановський О., Мунтіян В., Мосіюк М., Васильєв О., Зайченко В., Ушкаренко Ю.);

- інформаційно-правова (Глушков В.);

- екологічна (Барановський О., Мунтіян В., Мосіюк М., Васильєв О., Зайченко В., Ушкаренко Ю.);

- силова (Барановський О., Мунтіян В., Мосіюк М., Васильєв О., Козаченко Г., Зайченко В., Ушкаренко Ю.);

- безпека матеріальних ресурсів (Зубок М., Рубцов В.);

- безпека комерційної діяльності (Зубок М., Рубцов В.);

- безпека системи управління (Зубок М., Рубцов В.);

- кадрова (Васильєв О., Козаченко Г., Глушков В.);

- логістично-виробнича (Козаченко Г.);

- ринкова (Ушкаренко Ю.).

Таким чином, найбільшого поширення у публікаціях науковців здобули такі складові економічної безпеки, як фінансова, інтелектуальна і кадрова, політико-правова, інформаційна, екологічна і силова безпека. В умовах посилення корпоративної соціальної відповідальності, на чому акцентується увага в праці: [9], особливого пріоритету набуває кадрова безпека, що передбачає укомплектованість кадрами, заповнення вакансій, утримання та розвиток співробітників, розробку мотиваційних схем оплати праці, підвищення лояльності до співробітників тощо.

Варто зауважити, що рівень економічної безпеки підприємств прямо залежить від належним чином організованої системи їх економічної безпеки як сукупності елементів, взаємодія між якими спрямована на мінімізацію впливу загроз, що уможливлює злагоджене їх функціонування. Основними елементами такої системи справедливо вважаються об'єкт, суб'єкт, функціональні складові, нормативно-правове забезпечення, механізм її управління та функціонування.

Система економічної безпеки індивідуальна, її повнота значною 
мірою обумовлюється нормативно-правовою базою, наявними ресурсами, розумінням кожним працівником значення власне економічної безпеки. Основними об'єктами системи економічної безпеки підприємства, які $є$ взаємозумовленими і взаємопов'язаними, вважаються об'єкти обліку. До них належать необоротні та оборотні активи, власний капітал і зобов'язання.

Серед основних завдань в частині забезпечення економічної безпеки слід виокремити такі, як досягнення окресленої мети господарювання; розробка оптимальної організаційної структури управління; ефективне використання підприємницького потенціалу; посилення рівня фінансової стійкості, незалежності, ділової активності; створення технологічної незалежності і забезпечення конкурентоспроможності; підвищення рівня рентабельності; попередження негативного впливу можливих загроз зовнішнього середовища або ж спроможність їх оперативного усунення без створення негативних наслідків для конкретного суб'єкта господарювання; застосування екологічної політики для мінімізації негативного впливу на навколишнє середовище; підтримка юридично-правової захищеності та ін. До пріоритетних завдань, покликаних попередити зниження рівня економічної безпеки на мікрорівні, варто віднести розроблення способів уникнення можливих загроз та напрямів мінімізації негативних впливів зовнішнього і внутрішнього середовища, максимізацію якості збору та аналізу інформації щодо середовища функціонування і дій наявних конкурентів, посилення аналітичної роботи щодо витрат, доходів та фінансових результатів.

Така аналітична робота уможливлюється передусім завдяки організованій системі бухгалтерського обліку, адже формування достовірної інформації і пред'явлення її користувачам для ухвалення якісних рішень - основне завдання обліку, особливо за умов цифрової економіки [9].

Належним чином організована система бухгалтерського обліку дозволяє ефективно адмініструвати діяльність суб'єкта господарювання в сучасних соціально-економічних умовах завдяки реалізації виконання таких функцій: інформаційної, контрольної, правової регламентації, регулюючої, прогностичної.

Інформаційна функція. Формуючи об'єктивну, достовірну та оперативну інформацію про господарюючий суб'єкт бухгалтерський облік забезпечує користувачів даними про результати фінансової і господарської діяльності підприємства.

Функція правової регламентації полягає у фіксуванні кожного 
кроку господарської діяльності підприємства за допомогою необхідних для конкретної ситуації первинних документів. Здійснюючи правову регламентацію відповідно до законодавчонормативної бази, бухгалтерський облік дозволяє суб'єкту господарювання упорядковувати діяльність усіх своїх структурних елементів.

Контрольна функція дозволяє здійснювати нагляд та оперативне коригування діяльності підприємства. Потреба в здійсненні внутрішнього контролю з боку господарюючого суб'єкта обумовлена необхідністю підвищення ефективності його функціонування. Внутрішній контроль розглядається як процес, спрямований на отримання достатньої впевненості в тому, що суб'єкт господарювання забезпечує:

- здійснення ефективної та результативної діяльності;

- забезпечення достовірності та своєчасності формування та оприлюднення фінансової та іншої звітності;

- дотримання законодавства, особливо в сфері, що стосується ведення бухгалтерського обліку та здійснення фактів господарського життя.

Прогностична функція дозволяє знайти оптимальний шлях регулювання діяльності суб'єкта господарювання, тобто такий варіант управління, який би дозволив визначити найбільш пріоритетні напрямки його розвитку в майбутньому.

Регулююча функція допомагає здійснювати коригування діяльності підприємства протягом всього облікового процесу за результатами реалізації контрольної та прогностичної функцій.

Можемо зробити висновок, що адміністрація суб'єкта господарювання повинна організовувати систему внутрішнього контролю таким чином, щоб це дозволило скоротити вплив загроз і зловживань, які деформують дані бухгалтерського обліку в корисливих цілях.

Фінансова звітність повинна надавати достовірне уявлення про фінансовий стан підприємства, однак в ході ведення бухгалтерського обліку можуть виникати помилки, які спотворюють таку звітність. У зв'язку з цим виділяють наступні бухгалтерські помилки, які суб'єкт господарювання повинен нейтралізувати 3 метою забезпечення економічної безпеки на мікрорівні:

1) процедурні помилки (виникають при неправильному формуванні фінансової звітності):

- помилки у даті відображення господарської операції;

- відсутність первинних документів; 
- помилкове складання кореспонденції рахунків;

- невідображення або неповне відображення резервів в бухгалтерській звітності;

- некоректне відображення заборгованостей і зобов'язань.

2) технологічні помилки (виникають при використанні застарілих програм бухгалтерського обліку, збоїв в роботі комп'ютера):

- неправильне відображення показників у формах звітності;

- помилки в оцінці активів і зобов'язань.

В умовах активізації глобалізаційних процесів посилюється значення нефінансової звітності, що разом із фінансовою слугує базисом ухвалення різноманітних рішень і основою посилення транспарентності діяльності, що відображає прозорість відносин підприємства 3 іншими зацікавленими сторонами (інвесторами, власниками, працівниками, покупцями, постачальниками, громадою, державою). Транспарентність - це узагальнююча характеристика, яка складається 3 таких елементів, як фінансова та правова прозорість, прозорість управління, технологічна та соціальна прозорість. Транспарентність діяльності можу бути досягнуто завдяки формуванню й оприлюдненню інтегрованої звітності.

Запровадження інтегрованої звітності у практичну діяльність підприємств уможливлює правильне оцінювання ефективності їх діяльності у довгостроковій перспективі, забезпечує прозорість діяльності та поєднує всю суттєву фінансову і нефінансову інформацію, представляючи іï у зручній та зрозумілій для користувача формі.

Інтегрована (корпоративна) звітність - гармонізація фінансової та нефінансової звітності, де узагальнено інформацію про фінансовий стан та результати фінансово-господарської, соціальної та екологічної діяльності підприємств, що дає можливість оцінити ефективність прийнятих управлінських рішень та визначити стратегічні аспекти розвитку. Основною метою інтегрованої звітності $€$ надання достовірної інформації про всесторонню діяльність підприємства відповідно до стратегічних завдань та моделей управління [10].

Перелік показників, що наводиться в інтегрованій звітності, на рівні законодавства чітко не ідентифікований. Загалом він має ілюструвати інформацію про різноманітні аспекти діяльності (ефективність використання ресурсів, капіталу (фінансового, виробничого, людського, інтелектуального, екологічного, 
потенціалу), базуючись на якій, можливе оцінювання ризиків діяльності господарюючого суб'єкта. Основним джерелом такої інформації $\epsilon$, передусім, дані фінансової звітності. На даний час у фінансовій звітності не наводиться інформація про екологічний стан довкілля, економічні та соціальні досягнення, використання ресурсів, що важливо для управління. Інтегрована звітність з іiі орієнтацією на майбутнє характеризується високим рівнем прозорості і можливістю адаптації до діяльності будь-якого господарюючого суб'єкта. В сучасних умовах до формування інтегрованої звітності активно долучаються господарюючі суб'єкти різних країн світу.

Висновки і перспективи подальших розвідок. Встановлено, що економічна безпека $\epsilon$ одним із найважливіших функціональних напрямів національної безпеки країни та характеризує стан захищеності життєво важливих інтересів суспільства. Проведено аналіз трактування поняття «економічна безпека на мікрорівні», а також виокремлено іï функціональні складові. Обґрунтовано доцільність визначати економічну безпеку підприємства як такий стан функціонування, за якого максимально ефективно використовуються наявні ресурси 3 метою стабільного функціонування та динамічного розвитку, а також при цьому забезпечується незалежність, стійкість, можливість прогресу та уникнення внутрішніх і зовнішніх негативних дестабілізуючих факторів.

Визначено, що важливу роль у забезпеченні економічної безпеки суб'єкта господарювання відіграє система бухгалтерського обліку, яка дозволяє ефективно адмініструвати його діяльність в сучасних соціально-економічних умовах завдяки реалізації виконання таких функцій: інформаційної, правової регламентації, контрольної, прогностичної, регулюючої. Виокремлено основні бухгалтерські помилки, які підприємство повинно нейтралізувати 3 метою забезпечення економічної безпеки на мікрорівні. Обґрунтовано важливість інтегрованої звітності у забезпеченні транспарентної діяльності суб'єкта господарювання.

1. Павелко О.В. Фінансові результати основної діяльності будівельних підприємств: організаційно-методологічні засади обліку : монографія. Рівне : НУВГП, 2020. 604 с. URL: http://ep3.nuwm.edu.ua/20055 (дата звернення: 27.02.2021). 2. Козаченко Г. В., Пономарьов В. П., Ляшенко О. М. Економічна безпека підприємства: сутність та механізм забезпечення : монографія. К. : Лібра, 2003. 280 с. 3. Лянной Г. Система экономической безопасности предприятия. BOS журнал о личной и коммерческой безопасности. 2006. № 7. С. 16-19. 4. Зацеркляний М. М., Мельников О. Ф. Основи економічної безпеки : навч. посіб. К. : КНТ, 2009. 337 с. 5. Ковалев Д., Сухорукова Т. Экономическая безопасность 134 
предприятия. Экономика Украины. 1998. № 11. С. 48-52. 6. Козаченко Г. В., Пономарьов В.П. Економічна безпека підприємств: сутність і передумови формування. Теорія та практика управління у трансформаційний період : зб. наук. праць. Донецьк : IEП НАН України, 2001. Т. 3. С. 37. 7. Васильців Т. Г. Економічна безпека підприємництва України: стратегія та механізм зміцнення : монографія. Львів : ТзОВ «Ліга Прес», 2008. 385 с. 8. Motivational component of national corporate social responsibility: funding, accounting and reporting aspects / O. Osadcha, O. Pavelko, J. Nakonieczny, O. Zinkevych. International Journal of Business and Society. Vol. 21. No. 3, 2020. P. 1012-1032. URL: http://www.ijbs.unimas.my/index.php/content-abstract/current-issue/718motivational-component-of-national-corporate-social-responsibility-fundingaccounting-and-reporting-aspects (дата звернення: 27.02.2021). 9. Methodology of financial and economic analysis of innovative activities of enterprises in the conditions of the digital economy / O. Osadcha, O. Liashenko, O. Pavelko, R. Markov, N. Yurkiv. Financial and credit activity: problems of theory and practice. No. 35 (2020). Vol. 4. P. 202-211. URL: http://fkd1.ubs.edu.ua/article/view/222027 (дата звернення: 27.02.2021). 10. Проданчук М. А. Інтегрована звітність - інструмент управління підприємством. Бухгалтерський облік і аудит. 2014. № 2. С. 24-31.

\section{REFERENCES:}

1. Pavelko 0. V. Finansovi rezultaty osnovnoi diialnosti budivelnykh pidpryiemstv: orhanizatsiino-metodolohichni zasady obliku : monohrafiia. Rivne : NUVHP, 2020. 604 s. URL: http://ep3.nuwm.edu.ua/20055 (data zvernennia: 27.02.2021). 2. Kozachenko H. V., Ponomarov V. P., Liashenko O. M. Ekonomichna bezpeka pidpryiemstva: sutnist ta mekhanizm zabezpechennia : monohrafiia. K. : Libra, 2003. 280 s. 3. Lyannoy G. Sistema ekonomicheskoy bezopasnosti predpriyatiya. BOS jurnal o lichnoy i kommercheskoy bezopasnosti. 2006. № 7. S. 16-19. 4. Zatserklianyi M. M., Melnykov O. F. Osnovy ekonomichnoi bezpeky : navch. posib. K. : KNT, 2009. 337 s. 5. Kovalev D., Suhorukova T. Ekonomicheskaya bezopasnost predpriyatiya. Ekonomika Ukrainyi. 1998. № 11. S. 48-52. 6. Kozachenko H. V., Ponomarov V. P. Ekonomichna bezpeka pidpryiemstv: sutnist i peredumovy formuvannia. Teoriia ta praktyka upravlinnia u transformatsiinyi period : zb. nauk. prats. Donetsk : IEP NAN Ukrainy, 2001. T. 3. S. 37. 7. Vasyltsiv T. H. Ekonomichna bezpeka pidpryiemnytstva Ukrainy: stratehiia ta mekhanizm zmitsnennia : monohrafiia. Lviv : TzOV «Liha Pres», 2008. 385 s. 8. Motivational component of national corporate social responsibility: funding, accounting and reporting aspects / 0 . Osadcha, 0. Pavelko, J. Nakonieczny, 0. Zinkevych. International Journal of Business and Society. Vol. 21. No. 3, 2020. P. 1012-1032. URL: http://www.ijbs.unimas.my/index.php/contentabstract/current-issue/718-motivational-component-of-national-corporate-socialresponsibility-funding-accounting-and-reporting-aspects (дата звернення: 27.02.2021). 9. Methodology of financial and economic analysis of innovative activities of enterprises in the conditions of the digital economy / 0. Osadcha, O. Liashenko, O. Pavelko, R. Markov, N. Yurkiv. Financial and credit activity: problems of theory and $\begin{array}{lllll}\text { practice. } & \text { No. } 35 & \text { (2020). Vol. } 4 . & \text { P. 202-211. URL: }\end{array}$ http://fkd1.ubs.edu.ua/article/view/222027 (accessed: 27.02.2021). 10. Prodanchuk M. A. Intehrovana zvitnist - instrument upravlinnia pidpryiemstvom. Bukhhalterskyi oblik i audyt. 2014. № 2. S. 24-31. 
Osadcha 0. O. [1; ORCID ID:0000-0003-1314-3281], Doctor of Economics, Professor Pavelko O. V. [1; ORCID ID: 0000-0002-2483-2245], Doctor of Economics, Professor

${ }^{1}$ National University of Water and Environmental Engineering, Rivne

\section{MICROLEVEL OF ECONOMIC SECURITY: ACCOUNTING SUPPORT AND PROVISION OF TRANSPARENT ACTIVITY}

The article establishes that the globalization of the world economy, active integration of Ukraine's economy into international associations and the intensification of competition make demands on market participants to strengthen their own economic security. It is determined that economic security is one of the most important functional areas of national security and characterizes the state of protection of vital interests of society.

The analysis of the interpretation of the concept of "economic security at the micro level" is carried out, as well as its functional components are singled out. The expediency of defining the economic security of the enterprise as a state of protection of entrepreneurial potential from internal and external threats aimed at destabilizing balanced development, or a state of functioning in which the most efficient use of available resources for stable operation and dynamic development and independence, resilience, the possibility of progress and avoidance of internal and external negative destabilizing factors.

The main tasks in terms of ensuring economic security are presented: achieving the outlined management goal; development of optimal organizational management structure; effective use of entrepreneurial potential; strengthening the level of financial stability, independence, business activity; creation of technological independence and ensuring competitiveness; increasing the level of profitability; prevention of negative impact of possible threats to the environment; application of environmental policy to minimize the negative impact on the environment; support of legal protection.

It is determined that an important role in ensuring the economic security of the business entity is played by the accounting system, which allows to administer its activities in modern socio-economic conditions through the implementation of the following functions: information, legal regulation, control, forecasting, regulatory. The main accounting errors that the company must neutralize in order to ensure economic security at the micro level have been eliminated. The importance of integrated reporting in ensuring transparent activity of the business entity is substantiated. 
Keywords: micro level; macro level; meso level; economic security; accounting; transparent activity; enterprise; reporting; organization of accounting.

Осадчая О. А. [1; ORCID ID:0000-0003-1314-3281],

д.э.н., профессор

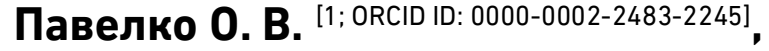
д.э.н., профессор

${ }^{1}$ Национальный университет водного хозяйства и природопользования, г. Ровно

\section{МИКРОУРОВЕНЬ ЭКОНОМИЧЕСКОЙ БЕЗОПАСНОСТИ: УЧЕТНОЕ СОПРОВОЖДЕНИЕ И ОБЕСПЕЧЕНИЕ ТРАНСПАРЕНТНОЙ ДЕЯТЕЛЬНОСТИ}

В статье исследована сущность экономической безопасности на микроуровне и ее функциональные составляющие. Определено, что важную роль в обеспечении экономической безопасности предприятия играет система бухгалтерского учета. Охарактеризованы основные функции учетной системы, которые позволяют предприятию достигать определенного уровня экономической безопасности: информационную, правовой регламентации, контрольную, прогностическую, регулирующую. Приведены основные бухгалтерские ошибки, которые предприятие должно нейтрализовать с целью обеспечения экономической безопасности на микроуровне. Обоснована важность интегрированной отчетности В обеспечении транспарентной деятельности предприятия.

Ключевые слова: микроуровень; макроуровень; мезоуровень; экономическая безопасность; учет; транспарентная деятельность; предприятие; отчетность; организация бухгалтерского учета.

Отримано: 28 лютого 2021 р. Прорецензовано: 05 березня 2021 р. Прийнято до друку: 26 березня 2021 р. 